\title{
The Role of Corporate Governance in Mitigating Real Earnings Management: Literature Review
}

\author{
Zakeya Sanad $^{1}$, Radha Shiwakotii ${ }^{1}$, and Gagan Kukreja ${ }^{2}$ \\ ${ }^{1}$ College of Business, Arts and Social Sciences, Brunel University London, UK \\ ${ }^{2}$ College of Business \& Finance, Ahlia University, Bahrain
}

\section{Abstract}

The purpose of this paper is to provide a critical review of the existing studies in the literature regarding real earnings management and corporate governance. The paper also addresses the gap in the real earnings management literature in the Gulf Cooperation Countries (GCC) as a major market in the Middle East and proposes future research topics.

Keywords: Earnings management, Real earnings management, corporate governance, board of directors.

Corresponding Author:

Zakeya Sanad

Zakeya.Sanad@brunel.ac.uk

Received: 22 July 2019

Accepted: 16 September 2019

Published: 19 September 2019

Publishing services provided by

Knowledge

(c) Zakeya Sanad et al. This article is distributed under the terms of the Creative Commons

Attribution License, which

permits unrestricted use and redistribution provided that the original author and source are credited.

Selection and Peer-review under the responsibility of the PwR Symposium Conference Committee.

\section{G OPEN ACCESS}

\section{Introduction}

A series of accounting scandals in the early 2000s had raised many concerns about the quality of reported earnings and matters related to their reliability and credibility. Many people argued that a central part of the accounting scandals was due to the conflict of interest between managers and shareholders (Jensen and Meckling, 1976), having this kind of conflicts can be reflected on the level of earnings management which leads to losses to investors, employees and the economy as a whole. Hence, the financial community started to demand transparent accounting information to able them to make the right use of resources, calculate the company's financial position, and predict the company's' future performance.

Accordingly, earnings management became a great concern to corporate stakeholders and much attention was given to the earnings management topic over the past years. Earnings management can be defined as the purposeful intervention in the financial reporting process to acquire private gain (Schipper, 1989). Healy \& Wahlen (1999) described that earnings management occurs when managers use their judgment in altering financial reports and structuring transactions to mislead stakeholders. Beatty (2002) defined earnings management as an informed decision-making process in compliance with accepted accounting principles to increase the reported earnings 
to the level desired by the management. Similarly, Sasaninejad et al. (2014) described earnings management as the intervention in the process of determining the profit which is performed in line with the management's desired goals.

The prior studies classified earnings management into accrual-based earnings management and real earnings management (Gunny, 2005). Both types of earnings management would increase the information asymmetry between managers and interested parties and hide a firm's actual performance, thereby, diminishing financial reporting reliability and credibility (Krishnan and McDermott 2012). However, the majority of the studies focused on investigating accrual-based earnings management (Call, et al. 2014: Sasaninejad, et al., 2014). However, previous studies noted that managers might manage the operational activities besides the accruals (Graham et al. 2005; Roychowdhury 2006; Badertscher 2011; Zang 2012).

Unlike accrual-based earnings management, in which managers manage earnings by taking advantage of the accounting discretion in GAAP, real earnings management involves the manipulation of earnings through real business activities (Xu, et al. 2007). Roychowdhury (2006) described real earnings managemnet activities as "departures from normal operational practices, motivated by managers' desire to mislead at least some stakeholders into believing certain financial goals have been met in the normal course of operations". The most common methods used in real earnings management are sales management, overproduction of units, the abnormal reduction of research and development (R\&D) expenses, timing the sale of fixed assets and the abnormal reduction of other discretionary expenditures. (Gunny 2005, Roychowdhury 2006, Ge and Kim, 2014; Talbi, 2015). These activities would increase the current year's earnings and allow the company to meet its financial reporting targets. On the other hand, these activities would result in reduced cash flows in the next years (Roychowdhury 2006). Hence, it misleads the stakeholders who are concerned by the current and future firm performance (Roychowdhury, 2006; Cohen and Zarowin, 2010).

\section{Literature Review}

Stock market regulators and investor protection agencies have been always concerned about earnings management, especially after the collapse of several large firms in recent decades. The review of prior literature mentioned that there are two common reasons why managers tend to manage earnings. The first reason is related to financial market pressures and contractual constraints mentioned by the positive political theory of accounting (Watts and Zimmerman, 1990; and Healy and Walhen, 1999). The 
second reason is to increase valuations and avoid negative regulatory and contracting consequences (Graham et al. 2005).

There are two possible ways to manage earnings: accruals management and real activities management (Gunny, 2005; Roychowdhury, 2006; Cohen et al., 2008). Accrual-based earnings management was extensively discussed in the literature (Schipper 1989; Healy and Wahlen 1999; Fields et al. 2001). However, real activities management as an earnings management tool was not well understood until recent years. Therefore, relatively few studies in the accounting literature investigated the management of real transactions to distort earnings. Graham et al. (2005) surveyed 401 executives. The results revealed that around $78 \%$ of executives prefer managing real activities over accrual-based earnings management to achieve their financial reporting objectives.

It is assumed that firms have different incentives to engage in real earnings management rather than accrual-based earnings management. Many studies showed that managers prefer to manage real business operations to meet earnings benchmarks (Baber et al. 1991; Bartov 1993; Roychowdhury 2006). Moreover, Chi et al. (2011) added that firms tend to engage in real activities management when their ability to manage accruals is limited by higher quality auditors. Besides, it is assumed that it is riskier to manage accrual-based earnings because it would easily draw regulatory investigations and auditor litigations. On the other side, stakeholders of a firm will find it difficult to investigate real activity management. This is supported by Kuo et al. (2014) who noted that Chinese firms have shifted from accruals management to real earnings management because it is less detectable. Furthermore, firms have many flexible options to manage with different activities (e.g. investing, operating, and financing activities). However, firms have limited options to manage accruals by altering accounting choices. Besides, managers can alter reported earnings at any time during the year at their convenience, whereas, accrual earnings management normally takes place as an expost form. A study by Ge and Kim (2014) showed that firms prefer to engage in real earnings management in the year of issuing their new bond to mislead rating agencies and accordingly have a lower bond yield spread. Based on what was mentioned above, the recent literature has focused on the investigations on real earnings management.

Previous studies had used different techniques to measure real earnings management (REM). Based on (Berger 1993; Roychowdhury 2006; Cohen et al. 2008; Cohen and Zarowin 2010; Zang 2012; Ge and Kim 2014) studies, they used four proxies to measure real earnings management: abnormal cash flow from operations as a proxy for sales management, abnormal production cost as a proxy for overproduction, the abnormal 
reduction of R\&D expenses, and the abnormal reduction of discretionary expenses (other than R\&D). Also, there are other methods used in prior studies to measure the level of real earnings management. Graham et al. (2004) stated that CFOs confessed cutting or delaying maintenance expenses and the travel budget. They further mentioned that they tend to postpone or eliminate capital investments to avoid depreciation charges, and they manage the funding of pension plans.

On the other hand, real earnings management would raise many concerns in the long term period. Gunny (2005) study analysis illustrated that real earnings management activities (sales management, sale of fixed assets, R\&D expenses reduction) have an economically significant negative impact on future operating performance. Besides, Eldenburg et al. (2011) found that firms with stronger performance incentives exhibit a significant incremental decrease in real expenditures in the future.

Real earnings management has remained a largely unexplored area in the literature. Graham et al. (2005) study revealed that managers prefer real activities management over accruals management. This study has motivated the researchers to focus their studies on real earnings management (e.g., Roychowdhury 2006; Cohen et al. 2008; Zang 2012; Talbi, 2015). Firms are switching from accrual-based earnings management to real earnings management (Cohen et al., 2008; Osma \& Young, 2009; Gunny, 2010). A study by Ewert and Wagenhofer (2005) noted that when firms are subject to tightening their regulation to improve their earnings quality may force the managers to seek for other management tools such as altering the business operations. Similarly, Cohen et al. (2008) study results indicated that the level of real earnings management activities increased significantly after the passage of SOX in 2002, while accrual-based earnings management declined. Besides, it is assumed that it is difficult for outsiders to detect real operating activities (Graham et al. 2005; Roychowdhury 2006; Cohen et al. 2008). Moreover, managing real activities is less costly to managers than firms and stakeholders (Gunny, 2005 \& 2010).

The recent collapse of some large companies resulting partially from accounting manipulation has raised serious questions about the role of different monitoring devices presumed to protect investors' interests and control managerial opportunistic behavior. Based on prior studies, corporate governance is considered one of the most effective monitoring devices. One of the most important monitoring devices is corporate governance. Investors and financial communities expressed concern about the reliability and the quality of reported earnings and the effectiveness of corporate governance systems. Companies started to pay a lot of attention to the need to achieve significant progress to corporate governance perform to assure investors' confidence in financial 
reporting quality. Davis (2005) had defined corporate governance as the processes, structures, and institutions within and around organizations that assign resource and power control among the participants.

Earnings management practices would result in producing a low quality of reported earnings that do not reflect a firm's real financial performance. And accordingly, it reduces the investors' confidence in the financial reports. Therefore, companies use different monitoring systems to eliminate managers' opportunistic behavior to increase the transparency and reliability of financial reports. Based on prior literature, it is widely accepted that corporate governance mechanisms can limit a manager's ability to manage earnings (e.g. Beasley, 1996; Dechow, et al., 1996; Jiambalvo, 1996; Peasnell et al., 2000; Chtourou et al., 2001; Xie et al., 2003; Park and Shin, 2004; Peasnell et al., 2005; Jaggi et al., 2009, Lo et al., 2010 and Dimitropoulos and Asteriou 2010). Dechow et al. (1995) mentioned that the main role of corporate governance is to sustain the credibility of financial statements and comply with reporting requirements. Shleifer and Vishny (1997) stated that corporate governance mechanisms could eliminate the inappropriate expropriation of firm resources by managers and it includes all the provisions required to ensure that the assets of firms are efficiently managed to protect the shareholders' interests.

Various mechanisms of corporate governance could affect the firm's performance and managerial behavior such as board composition, ownership structure, internal and external auditing, audit committee effectiveness, etc. Most of the corporate governancerelated studies classify the governance dimensions into two major classifications: ownership structure and board composition (Denis \& McConnell, 2003; Garcia \& Ballesta, 2009).

Board of directors plays an essential role in corporate governance as it is the center of control systems and decision-making (Fama \& Jensen, 1983). Fama (1980) mentioned that the board is considered one of the most significant corporate governance tools to monitor the managers' actions. Besides, the board contributes to mitigating the managerial self-serving behavior risk and as a result, enhancing firm value by lowering the agency costs (Shleifer \& Vishny, 1997).

The most effective monitoring tool used in corporate governance mechanisms is the board independence from the management (Beasley, 1996; Dechow et al., 1996). Baysinger \& Butler (1985) added that independent board members are expected to afford the greatest service to protect shareholders' interests and to monitor managers. Also, Beasley (1996) noted that the number of independent directors of the board is positively associated with the board's ability to influence the disclosure decisions. 
Likewise, Hussain (2009) stressed that a high level of board independence would result in enhanced transparency and responsibility using additional voluntary disclosure.

The extant literature shows substantial evidence that board independence is associated with accrual earnings management. Most of previous studies that tested the relationship between corporate governance and earnings management found a negative relationship between the board independence and the discretionary accounting accruals and the occurrence of fraudulent financial statements (Peasnell et al., 2000; Klein, 2002; Xie et al., 2003; Bedard et al., 2004; Park and Shin, 2004; Peasnell et al., 2005; Niu, 2006; Osma, 2008; Chang and Sun, 2009; Jaggi et al., 2009, Lo et al., 2010 and Dimitropoulos and Asteriou (2010). However, Abdul Rahman and Ali (2006) and Siregar and Utama (2008) studies found an insignificant relationship between either board independence or audit committee independence and earnings management. A year later, Iraya et al., (2015) documented a negative relationship between earnings management and ownership concentration, the board size, and board independence, while board activity and CEO duality are positively related to earnings management. Moreover, Patrick et al., (2015) illustrated that board size, firm size, board independence, and strength of the audit committee have a significant influence on earnings management.

On the other hand, as stated by Talbi et al. (2015), real earnings management has remained a largely unexplored area. Few studies discussed the board characteristics and real earnings management. Visvanathan (2008) tested the board of directors' attributes (independence, size, and duality) and the characteristics of audit committees (independence, size, and frequency of meetings) and their effects on real earnings management (discretionary spending, cash flow, and production) over the period 19962002. The results revealed that only the board independence, measured by the proportion of independent directors, has a significant negative effect on abnormal production. The researcher justified the lack of relationship between governance mechanisms and management of real activities by stating that real earnings management has limited empirical studies in the literature, therefore, there is a lack of work on detection. $\mathrm{He}$ also pointed out the fact that the managing real activities is complicated and accordingly, the establishment of methods for its detection is not an easy task.

A study conducted in the UK by Osma (2008) analyzed the role of boards of directors in constraining R\&D spending from the year 1989 up to 2002. The results reported that independent directors are capable of identifying and constraining real earnings management measured by the R\&D spending management. 
Furthermore, a Korean study by Kang and Kim (2012) determined whether corporate governance mechanisms affect a manager's real operating or investment decision to control reported earnings. The study used firms listed on the Korean Stock Exchange from the year 2005 to the year 2007. The study results indicated that earnings management decreases when the audit committee independence increases or the number of audit committee meetings increases. The results also showed that earnings management decreases when the number of board meetings increases, when the board size increases, when the number of independent directors increases, and when the number of directors who have long experience with the company increases.

Similarly, Talbi et al. (2015) study tested the efficacy of board attributes in restraining real earnings management in 7,481 US firms over the period 2000 to 2009 . The results revealed that the board's independence is negatively associated with the level of real earnings management. However, the number of directors is positively associated with the level of real earnings management. In addition, independent board committees are not associated with the level of real earnings management.

On the other hand, a study by Ge and Kim (2014) showed a different result than the above studies. The authors investigated the effect of board governance attributes and takeover protection on real earnings management. Real earnings management level was measured using four activities: overproduction, sales manipulation, the abnormal reduction of other discretionary expenditures, and the abnormal reduction of $R \& D$ expenses. The study used panel data from US public firms in the post-Sarbanes-Oxley Act period. The study findings revealed that the level of real earnings management is higher when a firm is faced with tough board monitoring, and that takeover protection may reduce managerial incentives for real earnings management.

\section{Future Studies}

Based on previous studies, accrual-based earnings management appears to be decreasing because managers realized that the risks and costs of accrual-based management to be higher than its benefits in a heightened regulatory environment. Besides, accruals mangement has been extensively studied in previous literature (e.g., Klein 2002; Xie et al. 2002; Peasnell et al. 2005; Cornett et al. 2006; Lin and Manowan 2012) while real earnings management has remained a largely unexplored area. Graham et al. (2005) study revealed that recently managers are using real activities to a greater extent than accounting actions to meet earnings benchmarks. Few studies investigated how certain corporate governance attributes relate to real earnings management and 
provide mixed evidence (Osma 2008; Visvanathan 2008; Zhao et al. 2012; Ge and Kim 2014; Malik 2015; Talbi et al. 2015).

Furthermore, Talbi et al. (2015) mentioned that real earnings management is more costly to firms and their stakeholders but is less costly to managers. Also, Roychowdhury (2006), Cohen et al. (2008), Cohen and Zarowin (2010) and Chan et al. (2014) agreed that real earnings management may impose high long-term costs on shareholders compared to accruals management, this is because of its negative effects on future cash flows and could affect the viability of the firm negatively. Ewert and Wagenhofer (2005) stated that when accounting regulation is tightened, accounting flexibility is reduced, and as a result, managers tend to use real earnings management techniques.

Corporate governance encompasses all the provisions and mechanisms that guarantee the assets of the firm are managed efficiently and in the interests of the providers of finance, mitigating the inappropriate expropriation of resources by managers or any other party to the firm (Shleifer and Vishny, 1997). The incorporation of independent directors to the board is expected to facilitate and improve the monitoring and control exerted by the board over senior managers, ensuring that managers act in the interests of investors. While there is general agreement that independent boards limit accounting accruals management, there is no previous evidence on whether these directors are capable of detecting and limiting real earnings management practices (Osma, 2008).

The developing markets and, particular, in a major market in the Middle East, which are the GCC countries, corporate governance practices have become an important topic recently. Numerous initiatives have addressed the corporate governance level in GCC countries. However, the prior studies showed that GCC countries, in general, are at their early stages of corporate governance improvement.

The tendency of managing real activities is a challenge to corporate governance practices, so it is interesting to investigate the role of corporate governance mechanisms in eliminating real earnings management. Most of the prior real earnings management studies focused on the U.S. and developed countries. Although GCC countries are considered as developing countries, the impact of the global financial crisis on the GCC region shows that countries in the GCC region are becoming increasingly integrated with the global economy. Thus, GCC countries have paid attention to enhance their corporate governance system. Foreign direct investments in the GCC countries have massively increased and accordingly, the need to improve corporate governance and reduce earnings management practices have become highly important. According to Habbash and Alghamdi (2015) study, Saudi managers are motivated to use earnings 
management practices due to different reasons, to increase their amount of remuneration, report a reasonable profit and avoid loss, obtain a bank loan and to increase share price. Numerous initiatives have addressed corporate governance practices to reduce opportunistic earnings management practices. However, prior studies have shown that GCC countries, in general, are at their early stage of corporate governance improvement. A study by Al-Matari et al. (2012) revealed that corporate governance in Saudi Arabia suffers from a weak legal framework, lack of accountability, and poor protection of shareholders. Baydoun et al. (2013) show that Oman is the leader among the five GCC countries, followed by Kuwait and the United Arab Emirates. Bahrain and Qatar rank fourth and fifth, respectively.

The existence of a relationship between the accrual-based earnings management corporate governance has been broadly supported by the literature, both in theoretical and empirical studies in the GCC countries (e.g. Al-Abbas, 2009; Alghamdi, 2012). Shubita (2015) assessed the practice of income smoothing practice in Saudi Arabia, Kuwait, United Arab Emirates, Oman, and Qatar. The study findings showed that income smoothing, on average, improves earnings quality in three countries out of four, however, not significantly for the whole sample.

A recent study by Habbash and Alghamdi (2017) investigated the association between audit quality and accrual-based earnings management in non-financial Saudi listed firms. The researchers claimed that the results of their study support the argument that auditors are powerless in front of managerial opportunistic earnings management activities. Kolsi and Grassa (2017) used a sample of Gulf Cooperation Council (GCC) Islamic banks to examine the impact of corporate governance mechanisms on accrualbased earnings management activities. The study revealed that a large board size, director's independence, and audit committee meetings are negatively associated with accrual-based earnings management.

Until now, the relationship between real earnings management and corporate governance is far from well understood in the Gulf Cooperation Countries (GCC) region. In the Gulf Cooperation Countries, there are limited studies that discussed corporate governance and real earnings management. Future studies can focus on the role of the board of directors and the audit committee in eliminating real earnings management practices. Accordingly, there is a need to understand the role of the board in promoting or constraining the real earnings management in the GCC. A future comparison study can be conducted between the different earnings management techniques to see whether the updated corporate governance regulations in the GCC region countries are effective in mitigating earnings management practices. Moreover, it would be also 
interesting to test the impact of institutional ownership and family ownership on real earnings management in the region since the family ownership level is relatively high in the GCC region.

Researchers can also link corporate social responsibility (CSR) with real earnings management. Countries are moving toward paying more attention to corporate social responsibility. For example, the United Arab Emirates Council of Ministers has issued a new Law concerning Corporate Social Responsibility (CSR) in the UAE which came into force in 2018. Some of the previous studies argued that there is a negative relationship between corporate social responsibility and earnings management because managers tend to mask their earnings management practices by being active in corporate social responsibility activities. Grougiou et al. (2014) study documented that although banks that engage in EM practices are also actively involved in corporate social responsibility activities. Scholtens and Kang (2013) study showed that Asian firms with relatively good corporate social responsibility level are engaged significantly less with earnings management. Due to the inclusive results provided by the previous studies, testing the relationship between corporate social responsibility, corporate governance and real earnings management in the GCC countries would be interesting.

\section{References}

[1] Abdul Rahman, R., and Ali, F.H.M. (2006) Board, Audit Committee, Culture and Earnings Management: Malaysian Evidence. Managerial Auditing Journal, Vol. 21, No. 7: pp. 783-804.

[2] Al-Abbas, M. A. (2009) Corporate governance and earnings management: An empirical study of the Saudi market. The Journal of American Academy of Business, Cambridge. 15 (01).

[3] AlGhamdi, S. (2012) Investigation into Earnings Management Practices and the Role of Corporate Governance and External Audit in Emerging Markets: Empirical Evidence from Saudi Listed Companies. A thesis submitted to Durham University in fulfillment of the requirements for the degree of Doctor of Philosophy. Durham University.

[4] Al-Matari, Yahya, Al-Swidi, Abdullah, Fadzil, Faudziah (2012) Corporate Governance and Performance of Saudi Arabia Listed Companies. British Journal of Arts and Social Sciences. Vol.9 No.I.

[5] Baber W, Fairfield P, Haggard J (1991) the effect of concern about reported income on discretionary spending decisions: the case of research and development. 
Accounting Review 66(4):818-829.

[6] Badertscher, B. (2011) Overvaluation and the choice of alternative earnings management mechanisms. The Accounting Review 86 (5): 1491-1518.

[7] Bartov E (1993) the timing of assets sales and earnings manipulation. Accounting Review 68(4):840-855.

[8] Baydoun, N., Maguire, W., Ryan, N., and Willett, R., (2013) Corporate governance in five Arabian Gulf countries. Managerial Auditing Journal. 2013, Vol. 28 Issue 1, p7-22. $16 p$.

[9] Baysinger, B., and H. Butler, 1985, Corporate governance and the board of directors: performance effects of changes in board composition, Journal of Law, Economics, and Organization 1, 101-124.

[10] Beasley, M. S. (1996) an empirical analysis of the relation between the board of director composition and financial statement fraud, The Accounting Review 71: 43 465.

[11] Beatty, A.; Ke, B.; Petroni, K., (2002), Earnings management to avoid earnings declines across publicly and privately held banks, The Accounting Review 77: 547570.

[12] Bedard, J., S. Chtourou, and L. Courteau, (2004) The effect of audit committee expertise, independence and activity on aggressive earnings management, Auditing: A Journal of Practice and Theory 23, 13 -35.

[13] Berger, P. (1993) Explicit and Implicit tax effects of the R\&D tax credit. Journal of Accounting Research. 31 (2): 131-171.

[14] Call, A., Chen, S., Miao, Tong, Y. (2014) Short-term earnings guidance and accrualbased.

[15] Chan, L-H., Chen, K-C-W., Chen, T-W., and Yu, Y. (2014) "Substitution between Real and Accruals-Based Earnings Management after Voluntary Adoption of Compensation Clawback Provisions" The Accounting Review, In-Press.

[16] Chi, W., Lisic, L. L. and Pevzner, M. (2011) Is Enhanced Audit Quality Associated with Greater Real Earnings Management? Accounting Horizons, Vol. 25, No. 2, pp. 315-335.

[17] Chtourou, S., J. Bédard, \& L. Courteau (2001). Corporate governance and earnings management. Working paper, University of Sfax, University of Laval, \& Free University of Bozen-Bolzano.

[18] Cohen DA, Dey A, Lys TZ (2008) Real and accrual-based earnings management in the pre- and post- Sarbanes Oxley periods. Accounting Review 82(3):757-787. 
[19] Cohen DA, Zarowin P (2010) Accrual-based and real earnings management activities around seasoned equity offerings. J Account Econ 50:2-19.

[20] Cornett, M.,Marcus, A., Saunders, A., \& Tehranian, H. (2006) Earnings management, corporate governance, and true financial performance. Accounting and Finance, 45, 241-267.

[21] Davis, G.F. (2005). New directions in corporate governance. Annual Review of Sociology, 31, 143-162.

[22] Dechow, P. M., Sloan, R. G. and Sweeney, A. P. (1995) Detecting earnings management, The Accounting Review, 70: 193-225.

[23] Dechow, P. M., Sloan, R. G. and Sweeney, A. P. (1996) Causes and consequences of earnings manipulation: An analysis of firms subject to enforcement actions by the SEC, Contemporary Accounting Research, 13: 1-36.

[24] Denis, D. \&McConnell, J. (2003) International corporate governance. Journal of Financial and Quantitative Analysis, 38: 1-36.

[25] Dimitropoulos, P.E., Asteriou, D. (2010). The Effect of Board Composition on the Informativeness and Quality of Annual Earnings: Empirical Evidence from Greece. Research in International Business and Finance, Vol. 24: pp. 190-205.

[26] earnings management. Rev Account Stud. 19:955-987.

[27] Eldenburg, L. J., Gunny, K. A., Hee, K. W., and Soderstrom, N. (2011) Earnings Management Using Real Activities: Evidence from Nonprofit Hospitals. The Accounting Review, Vol. 86, No. 5, pp. 1605-1630.

[28] Ewert, R. and Wagenhofer. A. (2005) Economic effects of tightening accounting standards to restrict earnings management, The Accounting Review, Vol. 80, pp. $1101-24$.

[29] Fama, E. (1980). Agency Problems and Theory of the Firm. Journal of Political Economy, Vol. 88: pp. 88-107.

[30] Fama, E. F. and Jensen, M. C. (1983) Separation of ownership and control, Journal of Law and Economics, 26: 319-337.

[31] Fields, T.D., Lys, T.Z., Vincent, L., (2001) Empirical research on accounting choice. Journal of Accounting and Economics 31, 255-307.

[32] García, M, Ballesta, JP. (2009) Corporate governance and earnings management: A meta-analysis. Corporate governance: an international review 17 (5), 594-610.

[33] Ge, W. and Kim, (2014) Boards, takeover protection, and real earnings management. Review of Quantitative Finance and Accounting, Vol. 43 (4) Pp 651-682. 
[34] Graham, J. R., C. R. Harvey, and S. Rajgopal (2005) The Economic Implications of Corporate Financial Reporting. Journal of Accounting and Economics 40: 3-73.

[35] Grougiou, V., Leventis, S., Dedoulis, E. and Owusu-Ansah, S., (2014) September. Corporate social responsibility and earnings management in US banks. In Accounting Forum (Vol. 38, No. 3, pp. 155-169). Taylor \& Francis.

[36] Gunny, K. (2005) What are the consequences of real earnings management? working paper, University of Colorado.

[37] Gunny, K. (2010) The relation between earnings management using real activities manipulation and future performance: Evidence from meeting earnings benchmarks. Contemporary Accounting Research, Vol. 27 No. 3, pp. 855-888.

[38] Habbash, M. and Alghamdi, S. (2017) Audit quality and earnings management in less developed economies: the case of Saudi Arabia. Journal of Management \& Governance, 21(2), pp.351-373.

[39] Habbash, M. and Alghamdi, S., 2015. The perception of earnings management motivations in Saudi public firms. Journal of Accounting in Emerging Economies, 5(1), pp.122-147.

[40] Healy, P. and Wahlen, J. (1999) A Review of the Earnings Management Literature and Its Implications for Standard Setting, Accounting Horizons, 13, 365-383.

[41] Hussain, S. (2009) Corporate Governance: Quantity Versus Quality-Middle Eastern Perspective. 79-129

[42] Iraya, C., Mwangi, M., \& Muchoki, G. W. (2015) The effect of corporate governance practices on earnings management of companies listed at the Nairobi securities exchange. European Scientific Journal, 11(1).

[43] Jaggi, B., Leung, S., and Gul, F. (2009) Family Control, Board Independence and Earnings Management: Evidence Based on Hong Kong Firms. Journal of Accounting and Public Policy, Vol. 28: pp. 281-300.

[44] Jensen, M. C., \& Meckling, W. H. (1976) Theory of the firm: Managerial behavior, agency costs and ownership structure. Journal of financial economics, 3(4), 305360. 27.

[45] Jiambalvo, J., (1996) Discussion of causes and consequences of earnings manipulation: an analysis of firms subject to enforcement by the SEC, Contemporary Accounting Research 13, 37.

[46] Kang, S.A. and Kim, Y.S. (2012) "Effect of corporate governance on real activity-based earnings management: Evidence from Korea" Journal of Business Economics and Management, Vol. 13 No. 1, pp. 29-52. 
[47] Klein, A (2002) Audit Committee, Board of Director Characteristics, and Earnings Management, Journal of Accounting and Economics 33(3), 375-400.

[48] Kolsi, M.C. and Grassa, R., 2017. Did corporate governance mechanisms affect earnings management? Further evidence from GCC Islamic banks. International Journal of Islamic and Middle Eastern Finance and Management, 10(1), pp.2-23.

[49] Krishnan GV, McDermott JB (2012) Earnings management and market liquidity. Review of Quantitative Finance and Accounting 38:257-274.

[50] Kuo, J-M., Ning, L. and Song, X. (2014) "The Real and Accrual-based Earnings Management Behaviors: Evidence from the Split Share Structure Reform in China" The International Journal of Accounting, Vol. 49, No. 1, pp. 101-136.

[51] Lin L, Manowan P (2012) Institutional ownership composition and earnings management. Rev Pac Basin Financ Mark Policy 15:1-22.

[52] Lo, A. W. Y., Wong, R. M. K. And Firth, M. (2010). Can corporate governance deter management from manipulating earnings? Evidence from related-party sales transactions in China. Journal of Corporate Finance, Vol. 16: pp. 225-235.

[53] Malik, Mahfuja (2015) Corporate Governance and Real Earnings Management: The Role of the Board and Institutional Investors. Journal of Knowledge Globalization. Vol 8, No 1.

[54] Niu, F.F. (2006). Corporate Governance and the Quality of Accounting Earnings: A Canadian Perspective. International Journal of Managerial Finance, Vol. 2, No. 4: pp. 302-327.

[55] Osma, B.G., Young, S. (2009) R\&D expenditure and earnings targets. European Accounting Review 18: 7.

[56] Park, Y.W., and Shin, H.H. (2004). Board Composition and Earnings Management in Canada. Journal of Corporate Finance, Vol. 10, No. 3): pp.4 31-457.

[57] Peasnell, K. V., Pope, P. F. and Young, S. (2000) Accrual management to meet earnings targets: UK evidence pre- and post- Cadbury, The British Accounting Review, 32: 415-445.

[58] Peasnell, K. V., Pope, P. F. and Young, S. (2005) Board Monitoring and Earnings Management: Do outside directors influence abnormal accruals? Journal of Business Finance Accounting, 32.

[59] Roychowdhury, S. (2006). Earnings Management through Real Activities Manipulation. Journal of Accounting and Economics 42: 335-370.

[60] Sasaninejad, Yaser, Madrakian, H., Khodabakhsh, A. (2014) Investigating the Relationship Between Corporate Governance Ranking and Earnings Management 
in Companies listed in Tehran Stock Exchange. Kuwait Chapter of Arabian Journal of Business and Management Review. Vol. 3, No.12. 302-309.

[61] Schipper, K. (1989) Commentary on earnings management, Accounting Horizons, 3: 91-102.

[62] Scholtens, B. and Kang, F.C., (2013) Corporate social responsibility and earnings management: Evidence from Asian economies. Corporate Social Responsibility and Environmental Management, 20(2), pp.95-112.

[63] Shleifer, A. and Vishny, R.W. (1997) A survey of corporate governance, Journal of Finance, Vol. 52, pp. 737-83.

[64] Shubita, M.F., (2015) The impact of income smoothing on earnings quality in emerging markets: Evidence from GCC markets. Journal of accounting in emerging economies, 5(3), pp.299-324.

[65] Siregar, S.V., and Utama, S. (2008). Type of Earnings Management and The Effect of Ownership Structure, Firm Size, and Corporate-Governance Practices: Evidence From Indonesia. The International Journal of Accounting, Vol. 43: pp. 1-27.

[66] Talbi, Dorra, Omri, M., Guesmi, K., Ftiti, Z. (2015) The Role of board Characteristics In Mitigating Management Opportunism: The Case Of Real Earnings Management. The Journal of Applied Business Research. Volume 31, Number 2. 661-674.

[67] Watts RL, Zimmerman JL (1990) Positive accounting theory: a ten year perspective. Accounting Review 65(1):131-156.

[68] Visvanathan G (2008) Corporate governance and real earnings management. Acad Account Financ Stud J12(1):9-22.

[69] Xie, B., Davidson, W. N., \& DaDalt, P. J. (2003). Earnings management and corporate governance: the role of the board and the audit committee. Journal of corporate finance, 9(3), 295-316.

[70] Xu, R. Z., G. K Taylor, M. T. Dugan, (2007). Review of real earnings management. Journal of Accounting Literature 26, 195 - 228.

[71] Zang, A. Y. (2012) Evidence on the trade-off between real activities manipulation and accrual-based earnings management. The Accounting Review, 87(2), 675-703.

[72] Zhao Y, Chen KH, Zhang Y, Davis M (2012) Takeover protection and managerial myopia: evidence from real earnings management. J Account Public Policy 31:109_ 135. 